\title{
GLYCEROL INCLUSION LEVELS IN CORN AND SUNFLOWER SILAGES
}

\author{
Níveis de inclusão de glicerol nas silagens de milho e girassol
}

\author{
Adriana de Souza Martins' ${ }^{1}$ Juliane Ribeiro de Oliveira ${ }^{2}$, Marili Lopes Lederer², \\ José Luís Moletta ${ }^{3}$, Shivelly Los Galetto ${ }^{2}$, Victor Breno Pedrosa ${ }^{2}$
}

\begin{abstract}
Due to the seasonal cycle of forage, the use of silage to feed animals provides nutrients throughout the year. However, its quality can be improved with the inclusion of additives and other products. Glycerol is a rich source of energy and present a high efficiency of utilization by animals. The purpose of this work was to evaluate the effect of glycerol inclusion on the chemical and fermentation characteristics of corn and sunflower silages. Two silage sources (maize and sunflower) were used and four levels of glycerol inclusion $(0,15,30$ and $45 \%)$ based on dry matter were carried out. The experimental design was completely randomized in a $2 \mathrm{x} 4$ factorial arrangement with five replications. The $\mathrm{pH}$ values and chemical composition of corn and sunflower silages were determined. In both silages there was increment of dry matter, non-fiber carbohydrates and total digestible nutrients (TDN) added to a reduction of crude protein, neutral detergent fiber and acid detergent fiber due to the glycerol inclusion. The corn silage required $45 \%$ glycerol to achieve the TDN level of the sunflower silage. The glycerol addition contributed to the increase in the nutritional value, offsetting loss of quality in the ensiling process.
\end{abstract}

Index terms: Crude glycerin, biofuels, dry matter, fermentation quality, conserved forage.

\section{RESUMO}

Em decorrência do ciclo estacional das forrageiras, o uso de silagem na alimentação animal permite o suprimento de nutrientes durante o ano todo. No entanto, sua qualidade pode ser melhorada com a inclusão de aditivos e outros produtos. O glicerol constitui uma fonte rica em energia e apresenta alta eficiência de utilização pelos animais. Assim, neste trabalho, objetivou-se avaliar o efeito da inclusão de glicerol nas silagens de milho e de girassol sobre as características bromatológicas e fermentativas do material ensilado. Foram utilizadas duas fontes de silagem (milho e girassol) e quatro níveis de inclusão de glicerol ( $0,15,30$ e $45 \%$ ), com base na matéria seca. O delineamento experimental foi o inteiramente casualizado, em esquema fatorial (2x4) com cinco repetições. Determinaram-se os valores de $\mathrm{pH}$ e da composição bromatológica das silagens de milho e de girassol.Em ambas as silagens houve incremento nos teores de matéria seca, carboidratos não fibrosos e nutrientes digestíveis totais (NDT), somados à redução de proteína bruta, fibra em detergente neutro e fibra em detergente ácido com a inclusão de glicerol. A silagem de milho necessitou de $45 \%$ de inclusão de glicerol para alcançar o teor de NDT da silagem de girassol. A inclusão de glicerol nas silagens de milho e de girassol contribui com o aumento no valor nutritivo, compensando possíveis perdas de qualidade no processo de ensilagem.

Termos para indexação: Glicerina bruta, biocombustíveis, matéria seca, qualidade de fermentação, forragem conservada.

\section{INTRODUCTION}

Due to the seasonal cycle pastures, tropical forages do not provide enough nutrients to meet animal nutrient requirements (Paciullo et al., 2008). Therefore, alternatives are needed to meet the demand of roughages such as the production of conserved forage as silage (Vieira et al., 2011), both throughout critical periods resulting from bad weather conditions and also as a supplement for confined animals. In this sense, the silage is an important strategy employed by the farmers to feed both beef and dairy cattle. The tropical regions are characterized by a high number of forage species with potential for silage. Some options are corn (Zea mays), sorghum (Sorghum bicolor) and sunflower (Helianthus annuus) (Oliveira et al., 2010; Viana et al., 2012).

The corn silage pattern has been considered due to its high yield of green mass per hectare, high nutritional value and wide acceptance by animals (Paziani et al., 2009), while the sunflower has been presented as an efficient alternative to silage production, mainly in regions where climatic conditions or year season are limiting for corn (Leite et al., 2006; Rezende et al., 2008).

One of the current priorities all over the world has been the use of alternative energy sources to circumvent problems caused by the technological development. The current concern about pollution reduction and energy crisis has encouraged the global biofuel market. Its production has helped to conserve the environment by reducing

\footnotetext{
${ }^{1}$ Universidade Estadual de Ponta Grossa/UEPG - Avenida General Carlos Cavalcanti, 4748 - Uvaranas - 84030-900 - Ponta Grossa - PR - Brasil dri261@yahoo.com.br

2Universidade Estadual de Ponta Grossa/UEPG - Ponta Grossa - PR - Brasil

${ }^{3}$ Instituto Agronômico do Paraná/IAPAR - Ponta Grossa - PR - Brasil

Received in april 21, 2014 and approved in august 20, 2014.
} 
the gases blamed for global warming (Basha; Gopal; Jebaraj, 2009). In December 2004 the National Program for Production and Use of Biodiesel was created with the aim of improving the viability of biodiesel. Its production generates byproducts with potential use in animal feed.

Glycerol, also known as crude glycerin, is a byproduct of the biodiesel production accounting for approximately $10 \%$ of the total volume produced (Dasari et al., 2007). This product results from the transesterification of triglycerides with alcohol (methanol or ethanol) and has impurities such as water, alcohol, and residual oil, which result in low cost (Ooiet al.,2004). Among the major agro-industrial co-products with potential uses in animal feed, currently stand out those coming from the biodiesel production, since with the mandatory inclusion of biodiesel to petroleum diesel and the growing demand for sustainable food production systems, there will be motivation to generate byproducts that have environmentally friendly and economically viable destinations (Lage et al., 2010). The use of glycerol in animal feed has attracted attention because it constitutes a rich product with high efficiency and energy utilization by animals. Additionally, the replacement of corn by glycerol can be an economically viable alternative in formulating rations for ruminants, especially when the price of corn is up, besides making available this cereal grain, which is widely used in food.

When used as an energy source in ruminant diets glycerol can be converted into glucose in the liver, providing energy for the cellular metabolism (Donkin, 2008) and when it is not recovered by the portal vein presumably can be converted into propionate in rumen, contributing to the gluconeogenesis (Chunget al., 2007). Donkin et al. (2009) consider glycerol as feed ingredient for cattle and may be included in the diet without deleterious effects, replacing corn in feed production.

Since 1950 most studies with glycerol have been based on small amountsadded to the diet because of its gluconeogenic characteristics (Chunget al., 2007; Leão et al., 2012). However, there is still little information on the use of glycerol added to tropical plant silages and its effects on the fermentation and nutritional quality (Oliveira et al.; 2013; Pereira et al., 2014).

According to Jobim et al. (2008) one way to improve the nutritional value of silage is through the use of additives or products with high energy/protein concentration. Therefore, the aim of this study was to evaluate the influence of levels of glycerol addition on the chemical and fermentation characteristics of corn and sunflower silages.

\section{MATERIAL AND METHODS}

The experiment was carried out at the Experimental Station of the Agronomic Institute of Paraná - IAPAR, located in Ponta Grossa, Paraná/Brazil.

The sowing of maize (cv. IPR-114) and sunflower (cv. Aguará-4) was held in October, 2010 with $0.80 \mathrm{~m}$ spacing and five seeds $\mathrm{m}^{-1}$ density. The maize received $316 \mathrm{~kg} \mathrm{ha}^{-1}$ NPK (10-30-10) and $129 \mathrm{~kg} \mathrm{ha}^{-1}$ nitrogen (N) in cover (V5 growth stage) as urea and the sunflower 400 $\mathrm{kg} \mathrm{ha}^{-1}$ NPK (00-25-25) and $200 \mathrm{~kg} \mathrm{ha}^{-1} \mathrm{~N}$ as urea, 35 days after sowing.

The maize harvest was held in February, 2011 when it presented an ideal spot for silage, i.e. the phenological stage R5 (50\% milk line). The harvesting of sunflower for silage was held in February, 2011when the disks are facing down and the dorsal part presents a "burnt yellow" coloring. The cutting height of maize and sunflower plants was $0.2 \mathrm{~m}$ above the soil.

After harvested, the sunflower and maize plants were ground separately and then homogenized and stored in experimental mini-silos, made of polyvinyl chloride plastic (PVC), $0.30 \mathrm{~m}$ long and $0.11 \mathrm{~m}$ in diameter, fitted with a Bunsen valve to eliminate gas from fermentation.

Treatments consisted of two silage sources (corn and sunflower) and four glycerol levels $(0,15,30$ and $45 \%$ dry matter) corresponding to $0 ; 130,258$ and $387 \mathrm{~g}$ glycerol in $0.860 \mathrm{~kg}$ corn silage (DM\%) and $0 ; 117 ; 235$ and $352 \mathrm{~g}$ glycerol in $0.782 \mathrm{~kg}$ sunflower silage (DM\%), respectively. The glycerol levels used in this study were slightly higher than those reported in the literature, in studies with silage. The choice of these levels aimed to determine the effects of higher levels in the silage quality, since according to previous research (Oliveira et al., 2013, Pereira et al., 2014) levels by $15 \%$ did not compromise its quality.

The glycerol used in the experiment had the following composition: $95.4 \% \mathrm{DM}, 0.4 \%$ ether extract (EE), $82 \%$ total digestible nutrients (TDN), 0,33\% methanol and $4.8 \%$ ash, being $35.8 \mathrm{mg} \mathrm{kg}^{-1}$ calcium; 239.8 $\mathrm{mg} \mathrm{kg}^{-1}$ phosphorus, $16.3 \mathrm{mg} \mathrm{kg}^{-1}$ magnesium and $79.1 \mathrm{mg}$ $\mathrm{kg}^{-1}$ potassium.

A layer of sand was added within each mini silo and weighed before and after the corn and sunflower ensiling to determine potential losses by leaching during the fermentation process. The mini silos were opened after 36 days and silage samples were collected for laboratory analysis. Nine grams of each sample were used for $\mathrm{pH}$ evaluation according to the methodology described by Silva and Queiroz (2002). A digital potentiometer was 
used to determine the $\mathrm{pH}$. Remainder samples were dried in oven with forced ventilation at $65^{\circ} \mathrm{C}$ for 72 hours and subsequently ground in a willey type mil to go through a $1.0 \mathrm{~mm}$ mesh. The DM, crude protein (CP), neutral detergent fiber (NDF), acid detergent fiber (ADF), ether extract (EE) and mineral matter (MM) contents were determined according to Silva and Queiroz (2002). The non-fiber carbohydrates (NFC) were calculated by the equation proposed by Weiss, Conrad and Pierre (1992): $\% \mathrm{NFC}=100-(\% \mathrm{NDF}+\% \mathrm{CP}+\% \mathrm{EE}+\% \mathrm{MM})$. The TDN values were calculated according to the equation proposed by Chandler (1990), where \%TDN $=105.2-$ $0.68 \times \%$ NDF.

The experimental design was completely randomized in a $2 \times 4$ factorial arrangement with five replicates (mini-silos) by treatment (source of silage and glycerol levels). The effect of quantitative variables (glycerol levels) was separately evaluated for each silage (corn and sunflower) and adjusted to regression models orthogonal, linear or quadratic polynomials $(\mathrm{P}<0.05$ or $\mathrm{P}<0.01)$. Data was submitted to ANOVA using the statistical program (SAS, 2010). Differences between silage sources and glycerol levels means were considered significant at $5 \%$ probability by the Tukey test.

\section{RESULTS AND DISCUSSION}

According to Ribeiro (2008) the best corn harvest for silage is defined as DM plant content and considered ideal when it presents 30 to $35 \% \mathrm{DM}$, because at this stage the plant presents a better relation between high dry matter yield, high starch and low fiber, providing a good fermentation profile to the ensiled mass and voluntary intake by animals. In this study, the DM content of corn silage in the control treatment $(0 \%$ glycerol) and in the $15 \%$ glycerol, was slightly below the ideal (Table 1).

Glycerol addition to the corn silage caused linear increase in the sand weight, reflecting the occurrence of a leaching process, commonly observed in ensiled materials. However, the silage DM, NFC and TDN increased $(\mathrm{P}<0.01)$ with the levels of glycerol, showing that a lot of the nutrients remained in the corn silage and was not lost through the leaching process. Therefore, the increase in sand weight may have been in part due to the flow of water from glycerol $(4.6 \%$ moisture) to the sand and, additionally, by the water formation resulting from the glycerol reaction with fatty acids present in the silage. According to Atkins and Jones (2012) for each 3.0 moles of fatty acids which react with $1.0 \mathrm{~mol}$ of glycerol, $1.0 \mathrm{~mol}$ of the oil/fat and 3.0 moles of water are formed. It appears that the linear increase in the sand weight with levels of glycerol is more related to the flow of water from the silage and to a lesser extent, to the leaching of nutrients (glycerol), since this led to an increase in DM and energy silage (NFC and TDN).

Table 1 - Means and equations of regression for sand weight $(\mathrm{g}), \mathrm{pH}$, dry matter $(\% \mathrm{MS})$, crude protein $(\% \mathrm{CP})$, neutral detergent fiber (\%NDF), acid detergent fiber (\%ADF), ether extract (\%EE), non-fiber carbohydrates (\%NFC) and total digestible nutrients (\%TDN) of corn silage according to the glycerol levels.

\begin{tabular}{|c|c|c|c|c|c|c|}
\hline \multirow[t]{2}{*}{ Parameter } & \multicolumn{4}{|c|}{ Glycerol level } & \multirow[t]{2}{*}{ Regression equation } & \multirow[t]{2}{*}{$\mathrm{R}^{2}$} \\
\hline & $0 \%$ & $15 \%$ & $30 \%$ & $45 \%$ & & \\
\hline Sand $^{1}$ & $30.5 \pm 8.9$ & $39.0 \pm 4.9$ & $40.2 \pm 5.4$ & $51.2 \pm 2.8$ & $\hat{y}=30.78+0.420 x$ & $0.61^{* *}$ \\
\hline $\mathrm{pH}$ & $3.9 \pm 0.0$ & $3.9 \pm 0.0$ & $4.0 \pm 0.0$ & $4.0 \pm 0.0$ & $\hat{\mathrm{y}}=\overline{\mathrm{y}}=4.0^{\mathrm{NS}}$ & - \\
\hline $\mathrm{DM}$ & $28.7 \pm 0.2$ & $29.1 \pm 0.3$ & $32.7 \pm 1.1$ & $34.7 \pm 1.0$ & $\hat{y}=27.98+0.145 x$ & $0.92^{* *}$ \\
\hline $\mathrm{CP}$ & $9.0 \pm 0.3$ & $7.7 \pm 0.8$ & $6.7 \pm 0.5$ & $5.6 \pm 0.2$ & $\hat{y}=8.95-0.075 x$ & $0.86^{* *}$ \\
\hline $\mathrm{NDF}$ & $48.6 \pm 1.8$ & $41.1 \pm 2.1$ & $32.8 \pm 1.5$ & $25.3 \pm 1.9$ & $\hat{y}=48.49-0.515 x$ & $0.96^{* *}$ \\
\hline $\mathrm{ADF}$ & $24.2 \pm 2.2$ & $18.3 \pm 1.3$ & $8.4 \pm 1.8$ & $4.3 \pm 1.6$ & $\hat{y}=24.27-0.463 x$ & $0.95^{* *}$ \\
\hline $\mathrm{EE}$ & $2.5 \pm 0.1$ & $2.0 \pm 0.1$ & $2.8 \pm 0.3$ & $1.6 \pm 0.1$ & $\hat{\mathrm{y}}=\overline{\mathrm{y}}=2.2^{\mathrm{NS}}$ & - \\
\hline $\mathrm{NFC}^{2}$ & $36.2 \pm 2.0$ & $44.8 \pm 2.6$ & $53.4 \pm 0.9$ & $62.8 \pm 1.9$ & $\hat{y}=36.29+0.582 x$ & $0.96^{* *}$ \\
\hline $\mathrm{TDN}^{3}$ & $72.2 \pm 1.2$ & $77.2 \pm 1.4$ & $82.9 \pm 1.0$ & $88.0 \pm 1.3$ & $\hat{y}=72.22+0.350 x$ & $0.96^{* *}$ \\
\hline
\end{tabular}

${ }^{1}$ Difference of weight (sand weight after ensiling - sand weight before ensiling). ${ }^{2} \% \mathrm{NFC}=100-(\% \mathrm{NDF}+\% \mathrm{CP}+\% \mathrm{EE}+\% \mathrm{MM})(\mathrm{Weiss}$, Conrad; Pierre, 1992). ${ }^{30} \% \mathrm{TDN}=105.2-0.68 \times$ x \%DF (Chandler, 1990). $* * \mathrm{P}<0,01 . \mathrm{NS}$ : no significant. 
The $\mathrm{pH}$ has an important effect on the silage mass conservation and its decline is due primarily to the production of lactic acid from bacteria action on soluble carbohydrates from the plant. The $\mathrm{pH}$ of corn silage was not changed $(\mathrm{P}>0.05)$ by the glycerol addition, with a mean value of 4.0. One of the glycerol chemical transformation reactions is oxidation, which may produce various compounds, among them glyceric acid, glycolic acid, oxalic acid and tartronic acid. According to Mota, Silva and Gonçalves (2009) the formation of these acids depends on factors such as temperature and catalysts, among others. Thus, the ensiling process conditions and corn plant characteristics did not allow significant increase in acid formation, which is evidenced by the constancy of the silage $\mathrm{pH}$ with higher levels of glycerol.

Cherney and Cox (2004) reported that silage is considered good quality when it presents $\mathrm{pH}$ between 3.8 and 4.2. Corn silage in this study showed $\mathrm{pH}$ values within the above range, even with the inclusion of $45 \%$ glycerol, demonstrating that it did not interfere with the fermentation process.

Increased levels of glycerol caused a proportional reduction in CP content of corn silage, and this was probably influenced by the composition of glycerol which has no nitrogenous substances, thus exerting dilutive effect (Mota; Silva; Gonçalves, 2009). Similarly, the corn silage NDF and ADF decreased with the addition of glycerol.

Possenti et al. (2005) evaluating the chemical composition of corn silages found levels of 63,32 and
62 of $\% \mathrm{NDF}, \mathrm{ADF}$ and TDN, respectively. In the present study, the addition of $45 \%$ glycerol in corn silage provided NDF and ADF means of $25.3 \%$ and $4.3 \%$, respectively, and for the NDT, levels of $88 \%$. According to Cruz et al. (2001), FDN values lower than $50 \%$ of the silage are more desirable since the consumption by ruminants is inversely related to the content of neutral detergent fiber. Therefore, these results reflect improvement in the quality of the silage with the glycerol addition.

The sunflower has important nutritional characteristics, such as high water content present in the seed oil, making it an interesting option as ensiled forage. In sunflower silage, the sand weight after ensiling increased linearly with the glycerol addition (Table 2).

The DM, NFC and TDN percentage also showed linear behavior with increasing levels of glycerol. As observed for corn silage, loss of nutrient (glycerol) by the leaching process was found to be negligible, since both the MS and the NFC and TDN contents increased with the addition of glycerol. Therefore, the increase in the sand weight was mainly due to an outflow of water from the silage.

The sunflower silage $\mathrm{pH}$ showed quadratic behavior, there was a decrease and subsequent increase with the addition of glycerol. As previously mentioned, depending on the environmental conditions, the oxidation of glycerol can lead to the formation of acids and these may have caused the drop in sunflower silage $\mathrm{pH}$ to the level of $30 \%$ glycerol ( $\mathrm{pH} 4.4)$. However, the reduction

Table 2 - Means and equations of regression for sand weight (g), $\mathrm{pH}$, dry matter (\%MS), crude protein (\%CP), neutral detergent fiber $(\% \mathrm{NDF})$, acid detergent fiber $(\% \mathrm{ADF})$, ether extract (\%EE), non-fiber carbohydrates (\%NFC) and total digestible nutrients (\%TDN) of sunflower silage according to the glycerol levels.

\begin{tabular}{|c|c|c|c|c|c|c|}
\hline \multirow[t]{2}{*}{ Parameter } & \multicolumn{4}{|c|}{ Glycerol level } & \multirow[t]{2}{*}{ Regression equation } & \multirow[t]{2}{*}{$\mathrm{R}^{2}$} \\
\hline & $0 \%$ & $15 \%$ & $30 \%$ & $45 \%$ & & \\
\hline Sand $^{1}$ & $2.9 \pm 4.0$ & $3.5 \pm 2.8$ & $16.2 \pm 3.9$ & $17.7 \pm 9.5$ & $\hat{y}=1.56+0.380 x$ & $0.60^{* *}$ \\
\hline $\mathrm{pH}$ & $4.8 \pm 0.2$ & $4.6 \pm 0.0$ & $4.4 \pm 0.0$ & $4.5 \pm 0.0$ & $\hat{y}=4.67-0.014 x+0.0002 x^{2}$ & $0.63^{* *}$ \\
\hline $\mathrm{DM}$ & $26.5 \pm 1.0$ & $27.1 \pm 1.0$ & $27.7 \pm 0.3$ & $31.4 \pm 0.7$ & $\hat{y}=25.91+0.100 x$ & $0.85^{* *}$ \\
\hline $\mathrm{CP}$ & $10.5 \pm 0.7$ & $9.5 \pm 0.3$ & $8.8 \pm 0.4$ & $8.4 \pm 0.8$ & $\hat{y}=10.33-0.046 x$ & $0.66^{* *}$ \\
\hline $\mathrm{NDF}$ & $39.9 \pm 2.8$ & $39.9 \pm 1.8$ & $31.4 \pm 2.8$ & $24.7 \pm 2.9$ & $\hat{y}=42.09-0.360 x$ & $0.86^{* *}$ \\
\hline $\mathrm{ADF}$ & $34.9 \pm 2.8$ & $32.5 \pm 0.6$ & $26.3 \pm 2.8$ & $22.1 \pm 2.3$ & $\hat{y}=35.63-0.296 x$ & $0.79^{* *}$ \\
\hline $\mathrm{EE}$ & $15.7 \pm 2.7$ & $13.7 \pm 0.6$ & $12.4 \pm 1.6$ & $15.7 \pm 1.4$ & $\hat{y}=15.59-0.255 x+0.006 x^{2}$ & $0.38^{*}$ \\
\hline $\mathrm{NFC}^{2}$ & $26.3 \pm 1.7$ & $29.4 \pm 1.6$ & $38.4 \pm 2.3$ & $41.2 \pm 2.9$ & $\hat{y}=25.77+0.357 x$ & $0.89^{* *}$ \\
\hline $\mathrm{TDN}^{3}$ & $81.2 \pm 1.7$ & $81.3 \pm 1.1$ & $86.3 \pm 1.7$ & $90.4 \pm 1.8$ & $\hat{y}=79.94+0.216 x$ & $0.86^{* *}$ \\
\hline
\end{tabular}

${ }^{1}$ Difference of weight (sand weight after ensiling - sand weight before ensiling) ${ }^{2} \% \mathrm{NFC}=100-(\% \mathrm{NDF}+\% \mathrm{CP}+\% \mathrm{EE}+\% \mathrm{MM})(\mathrm{Weiss}$, Conrad; Pierre, 1992). ${ }^{3 \%} \% \mathrm{TDN}=105.2-0.68 \times$ \% NDF (Chandler, 1990). ${ }^{*} \mathrm{P}<0,01 . \mathrm{NS}$ : no significant. 
in the silage acidity checked at $45 \%$ level ( $\mathrm{pH} 4.5$ ) can be explained by the Le Chatelier's principle, which states that when a system is in dynamic equilibrium and any change is applied to any of the equilibrium conditions, the system responds so as to fit to minimize the effect of the change (Atkins; Jones, 2012). Comparing sunflower and corn silages, the latter showed lower $\mathrm{pH}$ values, even zero glycerol level and no significant effect. Therefore, according to the Le Chatelier principle, the effect of acids derived from oxidation of glycerol would be less pronounced in corn silage, since the system was in balance regarding acidity.

Sunflower silage without glycerol showed $4.8 \mathrm{pH}$ and it was considered high to preserve the material quality. The inclusion of $30 \%$ glycerol promoted drop in $\mathrm{pH}$ to near-optimal levels. Oliveira et al. (2010) and Junior, Siewerdt and Harthmann (2008) obtained values of sunflower silage $\mathrm{pH} 4.3$ and 4.5, respectively.

Similarly to what had been observed for corn silage, $\mathrm{CP}, \mathrm{NDF}$ and ADF levels of sunflower silage decreased with glycerol inclusion, depending on the concentration effect. However, the EE level showed quadratic behavior with decrease and subsequent increase. The formation of oils from glycerol reaction with fatty acids (Atkin; Jones, 2012) present in sunflower silage may have caused increased levels of EE which later reduced due to the concentration effect.

The interactions between silage sources and glycerol levels to the sand weight and $\mathrm{pH}$ are shown in table 3.For the difference in sand weight there was no interaction $(\mathrm{P}>0.05)$ between silage source and glycerol levels. The sand weight was higher for corn silage (40.2 g) compared to sunflower silage (10.1 g), showing that the leaching process was less intense in the sunflower silage. This effect may be due to the sunflower characteristics, especially in relation to higher oil content, which may have avoided the flow of liquid between silage particles.

There was interaction $(\mathrm{P}<0.05)$ between silage sources and levels of glycerol regarding the $\mathrm{pH}$ values. At all levels of added glycerol, $\mathrm{pH}$ values of corn silage were lower when compared to the sunflower silage, being more suitable for proper preservation of the material. The higher sunflower silage $\mathrm{pH}$ was probably due to the higher $\mathrm{CP}$ content (Table 4) that during protein decomposition can produce nitrogen compounds that neutralize lactic acid, causing higher $\mathrm{pH}$ (Possenti et al., 2005).

Regarding DM, NDF, ADF, EE, NFC and TDN, the interaction between the level of glycerol and silage source was significant (Table 4). The corn silage DM content was higher when compared to the sunflower silage for all levels of glycerol inclusion. Oliveira et al. (2010) in a comparative study on the nutritional quality of different types of silage reported lower DM for sunflower silage (22-25\% DM) to be frequent, since the structure of this plant tissue has large amounts of moisture. Factors such as low-DM, temperature rise inside the silo and high buffer capacity of the forage can promote development of Clostridium bacteria which ferment sugars, proteins and produce lactic and butyric acids. This fermentation results in significant losses of dry matter and it reduces palatability and decreases silage stability, since butyric acid is low for preserving the silage (Oliveira et al., 2010).

Table 3 - Interaction between silage sources and glycerol levels for sand weight and $\mathrm{pH}$.

\begin{tabular}{|c|c|c|c|}
\hline $\begin{array}{c}\text { Glycerol } \\
\text { level }\end{array}$ & Corn silage & $\begin{array}{l}\text { Sunflower } \\
\text { silage }\end{array}$ & Mean $^{2}$ \\
\hline \multicolumn{4}{|c|}{ Sand $^{1}(\mathrm{~g})$} \\
\hline $0 \%$ & $30.5 \pm 8.9$ & $2.9 \pm 4.0$ & $16.7 \pm 13.8 \mathrm{C}$ \\
\hline $15 \%$ & $39.0 \pm 4.9$ & $3.5 \pm 2.8$ & $21.3 \pm 17.8 \mathrm{C}$ \\
\hline $30 \%$ & $40.2 \pm 5.4$ & $16.2 \pm 3.9$ & $28.2 \pm 12.0 \mathrm{~B}$ \\
\hline $45 \%$ & $51.2 \pm 2.8$ & $17.7 \pm 9.5$ & $34.5 \pm 15.1 \mathrm{~A}$ \\
\hline Mean $^{2}$ & $40.2 \pm 7.3 \mathrm{a}$ & $10.1 \pm 6.9 \mathrm{~b}$ & \\
\hline \multicolumn{4}{|c|}{$\mathrm{pH}$} \\
\hline $0 \%$ & $3.9 \pm 0.0 \mathrm{Ab}$ & $4.8 \pm 0.2 \mathrm{Aa}$ & - \\
\hline $15 \%$ & $3.9 \pm 0.0 \mathrm{Ab}$ & $4.6 \pm 0.0 \mathrm{Aa}$ & - \\
\hline $30 \%$ & $4.0 \pm 0.0 \mathrm{Ab}$ & $4.4 \pm 0.0 \mathrm{Aa}$ & - \\
\hline $45 \%$ & $4.0 \pm 0.0 \mathrm{Ab}$ & $4.5 \pm 0.0 \mathrm{Aa}$ & - \\
\hline
\end{tabular}

${ }^{1}$ Difference of weight (sand weight after ensiling - sand weight before ensiling). Means followed by different letters, small letters on the same row and capital letters on the same column, differ $(\mathrm{P}<0.05)$ by the Tukey test. ${ }^{2}$ Means showed only when there was no interaction effect.

According to the results of this study, corn and sunflower silages without glycerol showed DM values of 28.7 and $26.5 \%$ respectively, slightly below the recommended.

However, glycerol addition increased DM, which may have prevented the Clostridium proliferation as well as losses due to effluent. 
Table 4 - Mean values of dry matter (DM), crude protein (CP), neutral detergent fiber (NDF), acid detergent fiber (ADF), ether extract (EE), carbohydrates non-fiber carbohydrates (NFC) and total digestible nutrients (TDN) of corn and sunflower silages and effects of interaction between silage sources and glycerol levels.

\begin{tabular}{|c|c|c|c|}
\hline Glycerol level & Corn silage & Sunflower silage & Mean $^{3}$ \\
\hline \multicolumn{4}{|c|}{$\% \mathrm{DM}$} \\
\hline $0 \%$ & $28.7 \pm 0.2 \mathrm{Ca}$ & $26.5 \pm 1.0 \mathrm{Bb}$ & - \\
\hline $15 \%$ & $29.1 \pm 0.3 \mathrm{Ca}$ & $27.1 \pm 1.0 \mathrm{Bb}$ & - \\
\hline $30 \%$ & $32.7 \pm 1.1 \mathrm{Ba}$ & $27.7 \pm 0.3 \mathrm{Bb}$ & - \\
\hline $45 \%$ & $34.7 \pm 1.0 \mathrm{Aa}$ & $31.4 \pm 0.7 \mathrm{Ab}$ & - \\
\hline \multicolumn{4}{|c|}{$\% \mathrm{CP}$} \\
\hline $0 \%$ & $9.0 \pm 0.3$ & $10.5 \pm 0.7$ & $9.8 \pm 0.8 \mathrm{~A}$ \\
\hline $15 \%$ & $7.7 \pm 0.8$ & $9.5 \pm 0.3$ & $8.6 \pm 0.9 \mathrm{~B}$ \\
\hline $30 \%$ & $6.7 \pm 0.5$ & $8.8 \pm 0.4$ & $7.7 \pm 1.1 \mathrm{C}$ \\
\hline $45 \%$ & $5.6 \pm 0.2$ & $8.4 \pm 0.8$ & $7.0 \pm 1.4 \mathrm{D}$ \\
\hline Mean & $7.3 \pm 1.3 \mathrm{~b}$ & $9.3 \pm 0.8 \mathrm{a}$ & \\
\hline \multicolumn{4}{|c|}{$\% \mathrm{NDF}$} \\
\hline $0 \%$ & $48.6 \pm 1.6 \mathrm{Aa}$ & $39.9 \pm 2.8 \mathrm{Ab}$ & - \\
\hline $15 \%$ & $41.1 \pm 2.1 \mathrm{Ba}$ & $39.9 \pm 1.8 \mathrm{Aa}$ & - \\
\hline $30 \%$ & $32.8 \pm 1.5 \mathrm{Ca}$ & $31.4 \pm 2.8 \mathrm{Ba}$ & - \\
\hline $45 \%$ & $25.3 \pm 1.9 \mathrm{Da}$ & $24.7 \pm 2.9 \mathrm{Ca}$ & - \\
\hline \multicolumn{4}{|c|}{$\% \mathrm{ADF}$} \\
\hline $0 \%$ & $24.2 \pm 2.2 \mathrm{Ab}$ & $34.9 \pm 3.7 \mathrm{Aa}$ & - \\
\hline $15 \%$ & $18.3 \pm 1.3 \mathrm{Bb}$ & $32.5 \pm 0.6 \mathrm{Aa}$ & - \\
\hline $30 \%$ & $8.4 \pm 1.8 \mathrm{Cb}$ & $26.3 \pm 2.8 \mathrm{Ba}$ & - \\
\hline $45 \%$ & $4.3 \pm 1.6 \mathrm{Db}$ & $22.1 \pm 2.3 \mathrm{Ca}$ & - \\
\hline \multicolumn{4}{|c|}{$\% \mathrm{EE}$} \\
\hline $0 \%$ & $2.5 \pm 0.1 \mathrm{Ab}$ & $15.4 \pm 2.7 \mathrm{Aa}$ & - \\
\hline $15 \%$ & $2.0 \pm 0,1 \mathrm{Ab}$ & $13.7 \pm 0.6 \mathrm{Ba}$ & - \\
\hline $30 \%$ & $2.8 \pm 0.3 \mathrm{Ab}$ & $12.4 \pm 1.6 \mathrm{Ba}$ & - \\
\hline $45 \%$ & $1.6 \pm 0.1 \mathrm{Ab}$ & $15.7 \pm 1.4 \mathrm{Aa}$ & - \\
\hline \multicolumn{4}{|c|}{$\% \mathrm{NFC}^{1}$} \\
\hline $0 \%$ & $36.2 \pm 2.0 \mathrm{Da}$ & $26.3 \pm 1.7 \mathrm{Cb}$ & - \\
\hline $15 \%$ & $44.8 \pm 2.6 \mathrm{Ca}$ & $29.4 \pm 1.6 \mathrm{Bb}$ & - \\
\hline $30 \%$ & $53.4 \pm 0.9 \mathrm{Ba}$ & $38.4 \pm 2.3 \mathrm{Ab}$ & - \\
\hline $45 \%$ & $62.8 \pm 1.9 \mathrm{Aa}$ & $41.2 \pm 2.9 \mathrm{Ab}$ & - \\
\hline
\end{tabular}

Continue...

Ciênc. Agrotec., Lavras, v.38, n.5, p.497-505, set./out., 2014 
Table 4 - Continued...

\begin{tabular}{cccc}
\hline Glycerol level & Corn silage & Sunflower silage & Mean $^{3}$ \\
\hline & & $\% \mathrm{TDN}^{2}$ & \\
\hline $0 \%$ & $72.2 \pm 1.2 \mathrm{Db}$ & $81.2 \pm 1.7 \mathrm{Ca}$ & - \\
$15 \%$ & $77.2 \pm 1.4 \mathrm{Cb}$ & $81.3 \pm 1.1 \mathrm{Ca}$ & - \\
$30 \%$ & $82.9 \pm 1.0 \mathrm{Bb}$ & $86.3 \pm 1.7 \mathrm{Ba}$ & - \\
$45 \%$ & $88.0 \pm 1.3 \mathrm{Aa}$ & $90.4 \pm 1.8 \mathrm{Aa}$ & - \\
\hline
\end{tabular}

${ }^{1} \% \mathrm{NFC}=100-(\% \mathrm{TDN}+\% \mathrm{CP}+\% \mathrm{EE}+\% \mathrm{MM})$ (Weiss, Conrad; Pierre,1992). ${ }^{2 \% \mathrm{TDN}}=105.2-0.68 \mathrm{x} \% \mathrm{NDF}(\mathrm{Chandler}, 1990)$. Means followed by different letters, small letters on the same row and capital letters on the same column, differ $(\mathrm{P}<0.05)$ by the Tukeytest. ${ }^{3}$ Means showed only when there was no interaction effect.

Corn silage $\mathrm{CP}$ average was lower (7.3\%) than that of sunflower silage $(9.3 \%)$ and there was no interaction effect between silage sources and glycerol levels. Possenti et al. (2005) and Paziani et al. (2009) found values between 6.7 to $9.4 \%$ CP for corn silage and Viana et al. (2012) values between 11.6 and $12.1 \%$ for sunflower silage. The lower results for sunflower silage CP may be related to the variety and the vegetative stage of the plant at the time of cutting. There was proportional decrease of corn silage NDF with glycerol addition, nevertheless, significant decreased on NDF occurred only at 30 and $45 \%$ glycerol levels to the sunflower silage. The largest content of fiber in sunflower seed might have turned the effect of glycerol concentration less clear.

There was an increase in the corn silage CNF depending on the glycerol levels, however, for the sunflower silage, from the $30 \%$ glycerol CNF contents have not changed. Once added to the silage, glycerol, a source of available energy, may have acted as a substrate for microorganisms fermenting sugars, saving plant nutrients, including NFC.

Corn silage had lower TDN than sunflower silage at 0,15 and $30 \%$ glycerol, but with $45 \%$ glycerol addition, the TDN content of both silages was similar, suggesting that regarding energy, corn silage needs $45 \%$ glycerol to achieve the TDN content of sunflower silage, which is already more energy due to the higher oil content. Therefore, using levels of $45 \%$ glycerol it was possible to produce silage with $88 \%$ TDN. This result will reflect in increased animal performance compared to an average of silage with $70 \%$ TDN, and reduce the use of energy concentrates in the diet. Importantly, the increase in the energy content of the silage with inclusion of high levels of glycerol ( 30 and $45 \% \mathrm{DM}$ ) may restrict the consumption of forage, therefore, a maximum inclusion level that does not compromise performance or consumption of animals should be defined for each situation (i.e. forage source, chemical composition, supply, forage:concentrate ratio).

\section{CONCLUSIONS}

Glycerol improves the nutritional quality of corn and sunflower silages, increased the levels of energy and reduced fiber content. This co-product of biodiesel does not cause changes in the fermentation of ensiled forages with low $\mathrm{pH}$ and promotes acidification of silage materials with higher $\mathrm{pH}$, improving forage conservation. For both silages, levels of up to $45 \%$ glycerol contribute to the increase in nutritional value, allowing a reduction in the use of energy concentrated in animal feed. The choice for a certain level will take into consideration cost, availability of byproduct and/or restricting the forage intake. The option for the use of glycerol inclusion in silage compared to the use of concentrate brings compensating benefits related to the silage conservation and quality.

\section{REFERENCES}

ATKINS, P.; JONES, L. Princípios de Bioquímica 5.ed. Porto Alegre: Bookman, 2012. 1026p.

BASHA, S.A.; GOPAL, K.R.; JEBARAJ, S. A review on biodiesel production, combustion, emissions and performance. Renewable and Sustainable Energy Reviews. 13(6-7):1628-1634, 2009.

CHANDLER, P. Energy prediction of feeds by forage testing explorer. Feedstuffs. 62(36):12, 1990.

CHERNEY, D.J.R.; CHERNEY, J.H.; COX, W.J. Fermentation characteristics of corn forage ensiled in mini-silos. Journal of Dairy Science. 87(12):42384246, 2004. 
CHUNG, Y.H. et al. Effects of feeding dry glycerin to early postpartum holstein dairy cows on lactational performance and metabolic profiles. Journal of Dairy Science. 90(12):5682-5691, 2007.

CRUZ, J.C. et al. Produção e utilização de silagem de milho e sorgo. Sete Lagoas: Embrapa Milho e Sorgo, 2001. 544p.

DASARI,M. Crude glycerol potencial described. Feedstuffs. 79(43):16-19, 2007.

DONKIN, S.S. Glycerol from biodiesel production: the new corn for dairy cattle. Revista Brasileira de Zootecnia. 37(spe):280-286, 2008.

DONKIN, S.S. et al. Feeding value of glycerol as a replacement for corn grain in rations fed to lactating dairy cows. Jornal of Dairy Science. 92(10):5111-5119, 2009.

JOBIM, C.C. et al. Silagens de grãos de milho puro e com adição de grãos de soja, de girassol ou ureia.

Pesquisa Agropecuária Brasileira. 43(5):649-656, 2008.

JUNIOR, B.D.; SIEWERDT, L. HARTHMANN, L.E.O. Parâmetros qualitativo e nutricional da silagem de girassol pós-abertura de silo. Revista Brasileira de Agrociência. 14(2):369-373, 2008.

LAGE, J.F. et al. Glicerina bruta na dieta de cordeiros terminados em confinamentos. Pesquisa Agropecuária Brasileira. 45(9):1012-1020, 2010.

LEÃO, J.P. et al. Consumo e desempenho de bovinos de aptidão leiteira em confinamento alimentados com glicerol. Ciência Animal Brasileira. 13(4):421-428, 2012.

LEITE, L.A. et al. Silagens de girassol e de milho em dietas de vacas leiteiras: consumo e digestibilidade aparente. Arquivo Brasileiro de Medicina Veterinária e Zootecnia. 58(6):1192-1198, 2006.

MOTA, C.J.A.; SILVA, C.X.A.; GONÇALVES, V.L.C. Gliceroquímica: novos produtos e processos a partir da glicerina de produção do biodiesel. Química Nova. 32(3):639-648, 2009.

OLIVEIRA, L.B. et al. Perdas e valor nutritivo de silagens de milho, sorgo-sudão, sorgo forrageiro e girassol. Revista Brasileira de Zootecnia. 39(1):6167, 2010.

OLIVEIRA, J.S. et al. Frações de carboidratos da silagem de milho com adição de glicerina bruta. 2013. Disponível em: http://www.cnpgl.embrapa.br/ congresso2013/anais/artigos/producao/709.pdf. Acesso em: 24 de julho de 2014.

OOI, T.L. et al. Wan. Glycerol residue - a rich source of glycerol and medium chain fatty acids. Journal of Oleo Science. 53(1):29-33, 2004.

PACIULLO, D.S.C. et al. Disponibilidade de matéria seca, composição química e consumo de forragem em pastagem de capim-elefante nas estações do ano. Arquivo Brasileiro de Medicina Veterinária e Zootecnia.60(4):904-910, 2008.

PAZIANI, S.F. et al. Características agronômicas e bromatológicas de híbridos de milho para produção de silagem. Revista Brasileira de Zootecnia. 38(3):411417, 2009.

PEREIRA, S.N. et al. Determinação de perdas em silagem de capim-elefante com adição de diferentes níveis de glicerol e milho. 2014. Disponível em: http:// www.abz.org.br/publicacoes-tecnicas/anais-zootec/ artigos-cientificos/forragicultura-pastagens/78812Determinao-perdas-silagem-capim-elefante-com-adiodiferentes-nveis-glicerol-milho.html. Acesso em: 24 de julho de 2014.

POSSENTI, R.A. et al. Parâmetros bromatológicos e fermentativos das silagens de milho e girassol. Ciência Rural. 35(5):1185-1189, 2005.

REZENDE, A.V. et al. Uso de diferentes aditivos em silagem de capim-elefante. Ciência e Agrotecnologia. 32(4):281-287, 2008.

RIBEIRO, A.F. Influência da época de plantio e colheita na qualidade da silagem de milho. Rehagro, artigos técnicos, 2008. Disponível em: $<$ http://rehagro.com.br/plus/modulos/noticias/ ler.php?cdnoticia $=1815>$. Acesso em: 23 de julho de 2013.

SAS: Statistical Analysis System. SAS Online Doc ${ }^{\circledR}$ versão 9.2. Cary: SAS Institute, 2010. 
SILVA, D.J.; QUEIROZ, A.C. Análise de alimentos: métodos químicos e biológicos. 3.ed. Viçosa: UFV, 2002. 235p.

VIEIRA, V.C. et al. Caracterização da silagem de milho, produzida em propriedades rurais do sudoeste do Paraná. Revista Ceres. 58(4):462-469, 2011.
VIANA, P.T. et al. Fracionamento de carboidratos e de proteína das silagens de diferentes forrageiras. Revista Brasileira de Zootecnia. 41(2):292-297, 2012.

WEISS, W.P.; CONRAD, H.R.; PIERRE, N.R. A theoretically-based model for predicting total digestible nutrient values of forages and concentrates. Animal Feed Science and Technology. 39(1-2):95-110, 1992. 